\title{
STUDY ON THE SUSCEPTIBILITY OF Enterococcus faecalis FROM INFECTIOUS PROCESSES TO CIPROFLOXACIN AND VANCOMYCIN
}

\author{
GENARO A. (1), CUNHA M. L. R. S. (2), LOPES C. A. M. (2)
}

(1) Department of Tropical Diseases and Imaging Diagnosis, Botucatu School of Medicine, UNESP, São Paulo State University, São Paulo, Brazil; (2) Department of Microbiology and Immunology, Botucatu Institute of Biosciences, UNESP, São Paulo State University, Botucatu, São Paulo, Brazil.

ABSTRACT: Enterococcus faecalis is considered a pathogen responsible for hospital infections and, due to its frequent multi-resistant profile, has caused preoccupations among many medical authorities. The objective of this study was to determine the antimicrobial susceptibility of 74 strains isolated from blood cultures and purulent secretions to vancomycin and ciprofloxacin through the Minimum Inhibitory Concentration (MIC) and Minimum Bactericidal Concentration (MBC) by using the Microdilution test. The results showed a greater efficacy of vancomycin compared to ciprofloxacin $(98.6 \%$ of the strains were inhibited by vancomycin at lower concentrations: $0.06-1 \mu \mathrm{g} / \mathrm{ml})$. However, in the MBC analysis $73 \%$ of the strains showed a MBC of vancomycin only at high concentrations (equal to or higher than 64 $\mu \mathrm{g} / \mathrm{ml}$ ). For ciprofloxacin, the strains showed a broad sensitivity with MICs and MBCs distributed along all the MIC classes. Results also revealed a probability that some strains are tolerant to vancomycin, which indicates the need of other tests to confirm this characteristic.

KEY WORDS: Enterococcus faecalis, vancomycin, ciprofloxacin, resistance, spontaneous mutation.

\section{CORRESPONDENCE TO:}

A. GENARO, Department of Tropical Diseases and Imaging Diagnosis, Botucatu School of Medicine, UNESP, Distrito de Rubião Júnior, 18618-000, Botucatu, SP, Brazil. Phone: 143811 6212. Email: angelmagenaro@hotmail.com 


\section{INTRODUCTION}

Enterococci are enteric bacteria found in the human normal flora, mainly in the large intestine and genital-urinary tract, as well as in a variety of animal species. They became dreaded hospital pathogens in the 1990s, since many strains are very resistant to all conventional antibiotics, constituting the fourth most common cause of infections in the hospital context. Enterococci resistant to vancomycin have emerged as important pathogens responsible for a series of systemic infections. The E. faecalis species acquired an elevated level of resistance to aminoglycosides and glycopeptides. However, its resistance to ampicillin is still rare (16). An analysis of the data sent to the Center for Disease Control (CDC) in the United States, completed during the period between January 1989 and March 1993, showed a twenty-fold increase in the prevalence of Enterococci resistant to vancomycin associated with nosocomial infections (6). Nevertheless, recent studies have indicated the presence of Enterococcus faecalis strains sensitive to vancomycin and ciprofloxacin (4).

The available fluoroquinolones, including ciprofloxacin, are of limited interest in the treatment of infections by Enterococci, since they show moderate in vitro activity. However, new drugs have shown an increased activity against these pathogens. Thus fluoroquinolones may represent an alternative in the treatment of infections caused by these microorganisms (15). However, there is a concern regarding the emergence and rapid expansion of resistance acquisition to fluoroquinolones by Enterococci (19), as observed in the periods 1985-1986 and 1989-1990, in which a significant increase in the resistance to ciprofloxacin occurred (from 1\% to 15\%) among the Enterococcus faecalis strains (18).

The resistance of bacteria to quinolones arises due to alterations in the subunit gyrA gene (DNA gyrase); it was observed that a mutation in this gene in two strains of $E$. faecalis was the most responsible for the resistance to flouroquinolones (11). Yet, some authors suggested that another mechanism may be responsible for the resistance of some Enterococci to fluoroquinolones (8).

The present work sought to determine the antimicrobial sensitivity to ciprofloxacin and vancomycin in Enterococcus faecalis strains. 


\section{MATERIALS AND METHODS}

\section{Strains}

Seventy-four Enterococcus faecalis strains were studied in the Department of Microbiology and Immunology at the Botucatu Institute of Biosciences, UNESP - São Paulo State University, Botucatu, São Paulo, being all of them isolated from blood cultures and purulent secretions of patients hospitalized at the Clinical Hospital, Botucatu School of Medicine, UNESP, Botucatu, São Paulo, from 1995 to 2001.

This investigation was also approved by the Research Ethics Committee (OF. 094/2001) of the Clinical Hospital, Botucatu School of Medicine, UNESP, Botucatu, São Paulo.

\section{Drugs}

The bacteria antimicrobial sensitivity profile was studied in relation to vancomycin (Lilly) and ciprofloxacin (Bayer), according the National Committee for Clinical Standards (NCCLS-1999) (13).

\section{Determination of Minimum Inhibitory Concentration (MIC)}

Sensitivity to antimicrobials was evaluated by the microdilution test according the criteria stipulated by the National Committee for Clinical Laboratory Standards - NCCLS - M7A3 (12). The microplates were prepared by using a serial concentration of drugs $(0.06$, $0.125,0.25,0.5,1,2,4,8,16,32$ and $64 \mu \mathrm{g} / \mathrm{ml}$ ) in Mueller Hinton Broth (Difco) supplemented with $50 \mathrm{mg}$ of $\mathrm{Ca}^{++}$and $25 \mathrm{mg}$ of $\mathrm{Mg}^{++} / \mathrm{l}$ and innoculum compatible with $0.5 \mathrm{MacFarland}$ scale. Microplates were incubated for 18 hours at $35^{\circ} \mathrm{C}$, and for quality control a reference strain of Enterococcus faecalis (ATCC 29212) was used. The MIC was characterized as the lowest concentration of the drug that produced inhibition of the tested strain.

\section{Determination of Minimum Bactericidal Concentration (MBC)}

The methodology utilized was that reported by Stanholtzer (20) and Peterson (14). Accordingly, $100 \mu \mathrm{l}$ were aspirated from the wells of the microplate that showed growth inhibition and then inoculated on the surface of plates containing Columbia Agar Base added with 5\% defibrinated sheep blood. The MBC was characterized as the lowest 
concentration of the drug that produced the death of $99.99 \%$ of the bacteria in relation to the initial innoculum $\left(1 \times 10^{5} \mathrm{UFC} / \mathrm{ml}\right)$.

\section{Statistical Analysis}

The data, related to the percentage distribution of sensitive strains in the different classes of sensitivity, were statistically analyzed by the Goodman test $(2,3)$.

\section{RESULTS}

Data of MICs revealed vancomycin as the most effective antimicrobial drug, inhibiting $98.6 \%$ of the strains in class 1; only one strain, isolated from a gastric-surgery patient, showed an intermediary sensitivity pattern, with MIC of $16 \mu \mathrm{g} / \mathrm{ml}$. Ciprofloxacin showed an inhibitory activity in all the MIC classes, especially in class 1 with $48.6 \%$ of the strains (Table 1).

Our MBC analysis showed vancomycin as the most effective drug in class 4 with a bactericidal activity on $73 \%$ of the strains. There was no statistical difference for ciprofloxacin among the four classes of concentrations (Table 2). Both antimicrobial drugs were characterized by low $\mathrm{MIC}_{50 \%}$, whereas $\mathrm{MIC}_{90 \%}$ was elevated for ciprofloxacin. The two drugs presented high values of $\mathrm{MBC}_{90 \%}(>64 \mu \mathrm{g} / \mathrm{ml})$, as can be seen in Table 3.

Table 1. Susceptibility of 74 Enterococcus faecalis strains in four classes of MIC ( $\mu \mathrm{g} / \mathrm{ml})$.

\begin{tabular}{ccccc}
\hline \multicolumn{5}{c}{$\mathrm{n}(\%)$} \\
\hline Drugs & $\begin{array}{c}\mathrm{cl}-1 \\
(0.06-1 \mu \mathrm{l} / \mathrm{ml})\end{array}$ & $\begin{array}{c}\mathrm{cl}-2 \\
(2-4 \mu \mathrm{l} / \mathrm{ml})\end{array}$ & $\begin{array}{c}\mathrm{cl}-3 \\
(8-32 \mu \mathrm{l} / \mathrm{ml})\end{array}$ & $\begin{array}{c}\mathrm{cl}-4 \\
(\geq 64 \mu \mathrm{l} / \mathrm{ml})\end{array}$ \\
\hline Vancomycin & 73 & 0 & 1 & 0 \\
& $(98.6)$ & $(0.0)$ & $(1.4)$ & $(0.0)$ \\
\hline Ciprofloxacin & 36 & 21 & 13 & 4 \\
& $(48.6)$ & $(28.4)$ & $(17.6)$ & $(5.4)$ \\
\hline
\end{tabular}

cl-1 = class 1 of concentration; cl-2 = class 2 of concentration; cl-3 = class 3 of concentration; $\mathrm{cl}-4=$ class 4 of concentration; MIC= Minimum Inhibitory Concentration 
Table 2. Susceptibility of 74 Enterococcus faecalis strains in four classes of MBC $(\mu \mathrm{g} / \mathrm{ml})$.

\begin{tabular}{ccccc}
\hline \multicolumn{5}{c}{$\mathrm{n}(\%)$} \\
\hline Drugs & $\begin{array}{c}\mathrm{cl}-1 \\
(0.06-1 \mu \mathrm{l} / \mathrm{ml})\end{array}$ & $\begin{array}{c}\mathrm{cl}-2 \\
(2-4 \mu \mathrm{l} / \mathrm{ml})\end{array}$ & $\begin{array}{c}\mathrm{cl}-3 \\
(8-32 \mu \mathrm{l} / \mathrm{ml})\end{array}$ & $\begin{array}{c}\mathrm{cl}-4 \\
(\geq 64 \mu \mathrm{l} / \mathrm{ml})\end{array}$ \\
\hline Vancomycin & 6 & 5 & 9 & 54 \\
& $(8.1)$ & $(6.7)$ & $(12.2)$ & $(73)$ \\
\hline Ciprofloxacin & 19 & 17 & 14 & 24 \\
& $(25.7)$ & $(23)$ & $(18.9)$ & $(32.4)$ \\
\hline cl-1 = class 1 of concentration; cl-2 = class 2 of concentration; cl-3 = class 3 of concentration; \\
cl-4 = class 4 of concentration; MBC=Minimum Bactericidal Concentration
\end{tabular}

Table 3. Populational MICs and MBCs ( $\mu \mathrm{g} / \mathrm{ml})$ among 74 Enterococcus faecalis strains.

\begin{tabular}{|c|c|c|c|c|c|c|}
\hline \multirow{2}{*}{ Drugs } & \multicolumn{6}{|c|}{ Range } \\
\hline & $\mathrm{MIC}_{50 \%}$ & $\mathrm{MBC}_{50 \%}$ & $\mathrm{MIC}_{90 \%}$ & $\mathrm{MBC}_{90 \%}$ & MIC & $\mathrm{MBC}$ \\
\hline Ciprofloxacin & 0.96 & 6 & 14.7 & $>64$ & $0.125->64$ & $0.5->64$ \\
\hline Vancomycin & 0.55 & $>64$ & 0.92 & $>64$ & $0.25-16$ & $0.5->64$ \\
\hline \multicolumn{7}{|c|}{$\begin{array}{l}\mathrm{MIC}_{50 \%}=\text { Minimum Inhibitory Concentration 50\%; } \mathrm{MBC}_{50 \%}=\text { Minimum Bactericidal Concentration } \\
50 \% ; \mathrm{MIC}_{90 \%}=\text { Minimum Inhibitory Concentration } 90 \% ; \mathrm{MBC}_{90 \%}=\text { Minimum Bactericida } \\
\text { Concentration } 90 \% ; \mathrm{MIC}=\text { Minimum Inhibitory Concentration; } \mathrm{MBC}=\text { Minimum Bactericida } \\
\text { Concentration }\end{array}$} \\
\hline
\end{tabular}

\section{DISCUSSION}

The emergence of resistance to antimicrobials in bacteria has been considered a serious problem in the therapy of infections in immuno-suppressed patients, especially when the surrounding germs are endowed with innumerable factors of virulence and genetic mechanisms for acquisition of this characteristic (7). In this context, the establishment of therapeutic strategies to control or even impede the dissemination of antimicrobial multi-resistance among opportunistic pathogens constitutes an indispensable public-health resource (11).

Our results, regarding sensitivity percentages of Enterococcus faecalis strains, obtained by determination of the Minimum Inhibitory Concentration, showed a greater efficacy of 
vancomycin compared to ciprofloxacin, since the former inhibited $98.6 \%$ of the strains studied in the class of concentrations varying from 0.06 to $1 \mu \mathrm{g} / \mathrm{ml}$. This phenomenon was not observed for ciprofloxacin, in which inhibition occurred in all the MIC classes, but was most representative in class 1 (48.6\% of the strains). These results also have been observed by other authors, who found Enterococcus faecalis strains sensitive to vancomycin $(1,21)$. Regarding this, there are few references in literature that demonstrated the presence of $E$. faecalis strains resistant to vancomycin and ciprofloxacin and, among these, some authors who verified the emergence of $E$. faecalis strains resistant to these antimicrobials (5). Yet, in our study, we characterize a strain with intermediary resistance to vancomycin (MIC of $16 \mu \mathrm{g} / \mathrm{ml}$ ), isolated from a gastricsurgery patient; a phenomenon observed by other authors (17). The analysis of bactericidal activity showed that vancomycin was effective in $73 \%$ of the strains in concentrations higher than or equal to $64 \mu \mathrm{g} / \mathrm{ml}$. Regarding ciprofloxacin, bactericidal activity was observed in all the MBC classes analyzed. These results, mainly with respect to vancomycin, are extremely significant because this drug is considered to have an inhibitory effect, in conformity with literature data, and bactericidal effect only in elevated concentrations. Although it would be a difficult task to discuss these results in light of the literature, our observations are similar to those of other authors, who verified that although $E$. faecalis strains presented $\mathrm{MIC}_{90}$ of $2 \mu \mathrm{g} / \mathrm{ml}$ for vancomycin, these were considered tolerant to the drug due to the elevated $\mathrm{MBC}_{50 \%}$ and $\mathrm{MBC}_{90 \%}$ (10). Faced with these results, it is possible to emphasize a necessary concern that vancomycin presents unquestionable bactericidal activity and does not provide to the same extent the expected bactericidal effect. It is important to consider that, regarding vancomycin, aspects related to the incubation time are determinants in the results, since this antimicrobial permits slow action in the stationary phase of bacteria growth, in which reincubation is necessary, and also completion of duplicate tests to better characterize the discrepancy among the results (9). However, in the context of our results, we cannot discount the possibility that some strains could be tolerant to vancomycin. Based on the results obtained, we consider important to note that the antimicrobial evaluation of vancomycin, in terms of bactericidal activity, must be investigated by other methodologies that could better elucidate the characterization of strains possibly tolerant 
to the drug and that represent risk of therapeutic strategies in the ultimate instance.

\section{REFERENCES}

1 ELIOPOULOS GM., REISZNER E., MOELLERING RCJR. In vitro activity of Sch 343443 against enterococci and other gram positive bacteria. Antimicrob. Agents Chemother., 1985, 27, 28-32.

2 GOODMAN LA. Simultaneous confidence intervals for contrasts among multinomial populations. Ann. Math. Stat., 1964, 35, 716-25.

3 GOODMAN LA. On simultaneous confidence intervals for multinomial proportions. Technometrics, 1965, 7, 247-54.

4 HALLGREN A., ABEDNAZARI H., EKDAHL C., HANBERGER H., NILSSON M., SAMUELSSON A. Antimicrobial susceptibility patterns of enterococci in intensive care units in Sweden evaluated by different MIC breakpoint systems. J. Antimicrob. Chemother., 2001, 48, 53-62.

5 JOHNSON AP., WARNER M., WOODFORD N., SPELLER DCE., LIVERNORE DM. Antibiotic resistance among enterococci causing endocarditis in the UK: analysis of isolates referred to a reference laboratory. Br. Med. J., 1998, 317, 629-30.

6 JONES RN. Disk diffusion susceptibility test development for the new glycylcycline, GAR-936. Diagn. Microbiol. Infect. Dis., 1995, 35, 249-52.

7 KADURUGAMUWA JL., BEVERIDGE TJ. Virulence factor are released from Pseudomonas aeruginosa in association with membrane vesicles during normal growth and exposure to gentamicin: novel mechanism of enzyme secretion. J. Bacteriol., 1995, 177, 3998-4008.

8 KORTEN V., HUANG WM., MURRAY BE. Analysis by PCR and direct DNA sequencing of gyrA mutations associated with fluoroquinolone resistance in Enterococcus faecalis. Antimicrob. Agents Chemother., 1994, 38, 2091-4.

9 LANCE R., PETERSON MD., SUSAN M., COLINS MT. Bactericidal testing for infectious disease therapy: the why and how to measure if we kill the bugs. Clin. Microbiol. Newsl., 2000, 22, 153-7. 
10 LOUIE A., BALTCH AL., RITZ WJ., SMITH RP., ASPERILLA M. Comparison of in vitro inhibitory and bactericidal activities of daptomycin (LY 146032) and four reference antibiotics, singly and in combination, against gentamicin-susceptible and high-gentamicin-resistant enterococci. Chemotherapy, 1993, 39, 302-9.

11 MENDES CMF, SADER HS. Importância do laboratório de microbiologia no apoio à investigação de surtos de infecção hospitalar. J. Bras. Patol., 1997, 33, 203-12.

12 NATIONAL COMMITTEE FOR CLINICAL LABORATORY STANDARDS. Methods for dilution antimicrobial susceptibility test for bacteria that grow aerobically: approved standard. Villanova: NCCLS, 1997. (M7-A3).

13 NATIONAL COMMITTEE FOR CLINICAL LABORATORY STANDARDS. Performance standards for antimicrobial susceptibility testing: ninth informational suplement. Villanova: NCCLS, 1999. (M100-S9).

14 PETTERSON JE., ZERVOS MJ. High-level gentamicin resistance in enterococcus: microbiology, genetics basis and epidemiology. Rev. Infect. Dis., 1990, 12, 64452.

15 SAHM DF., KOBUROV GT. In vitro activities of quinolones enterococci resistant to penicillin-aminoglycoside synergy. Antimicrob. Agents Chemother., 1989, 33, 717.

16 SASTRY V., BRENNAN PJ., LEVY MM. Vancomycin-resistant enterococci: an emerging pathogen in immunosuppressed transplant recipients. Transplant. Proc., 1995, 27, 954-5.

17 SAWICKA-GRZELAK A., ROSZ A., LUCZA KM. Drug resistance of 100 clinical strains of Enterococcus ssp. Med. Dosw. Mikrobiol., 1999, 51, 239-47.

18 SHABERG DR., DILON WL., TERPENNING MS., ROBINSON KA., BRADLEY SF., KAUFFMAN CA. Increasing resistance of enterococci to ciprofloxacin. Antimicrob. Agents Chemother., 1992, 36, 2533-5.

19 SHALIT L., BERGER SA., GOREA A., FRIMERMAN H. Widespread quinolone resistance among methicilin-resistant Staphylococcus aureus isolates in a general hospital. Antimicrob. Agents Chemother., 1989, 35, 593-4. 
A. Genaro et al. STUDY ON THE SUSCEPTIBILITY OF Enterococcus faecalis FROM INFECTIOUS PROCESSES TO CIPROFLOXACIN AND VANCOMYCIN. J.Venom. Anim. Toxins incl. Trop. Dis., 2005, 11, 3, p. 260

20 STANHOLTEZER GM., WENNERSTEN C., ZIGHELBOIM-DAUM S., REISZNER E., GOLDMANN D., MOELLERING RC. High-level resistance to gentamicin in clinical isolates of Streptococcus faecium. Antimicrob. Agents Chemother., 1986, 32, 1528-32.

21 VERGIS ENMD, HAYDEN MK, CHON JW., SNYDMAN DR., ZERVOS MJ., LINDEN PK. Determinants of vancomycin resistance and mortality rates in enterococcal bacteremia: a prospective multicenter study. Ann. Int. Med., 2001, 135, 484-92. 